магістер-туризмознавець, факультет туризу та міжнародних комунікаиій ДВНЗ «Ужгородський національний університет» (Ужгород, Украӥна), ursztika@gmail.com

\title{
ІСТОРІЯ РОЗВИТКУ ОСНОВНИХ НАПРЯМІВ ТУРИЗМУ В УКРАЇНІ: СОЦІАЛЬНО-ЕКОНОМІЧНІ АСПЕКТИ
}

У статті проаналізовано історію розвитку основних напрямів вітчизняної туристичної галузі. Авторка дійшла висновку, що становлення рекреачійно-туристичної діяльності на теренах українських земель відбувалося щзе за часів Давньої Греиії. У Північному Причорномор ї були засновані міста-колонії, найбільшими з яких були Тіра, Ольвія, Херсонес, Пантікапей, Феодосія, Свпаторія, в яких використовували лікувальні води, грязі кримських озер і лиманів. Перші згадки про родовища лікувальних вод на заході України (Моршин, Немирів, Поляна, Синяк, Любень Великий) датовані XVI cm. У другій половині XVIII ст. в Україні почався швидкий розвиток курортів. Здійснювалося будівництво водолікарень, готелів, будинків для приїжджих, відбувалася комерціалізація курортної справи, тривали дослідження й пошуки нових родовищ. У радянський час туристична галузь була зорієнтована на рекреацію. Масово будувалися санаторії, великі і малі оздоровниці.

На початку 90-х рр. туристична галузь функціонувала, базуючись на радянських санаторно-курортних об'єктах та виїзному туризмі.

Розкриття теми стало можливим завдяки використанню загальнонаукових методів пізнання: аналізу, синтезу, системності, узагальнення, конкретності, історизму та діалектичного. Також використано спеціально наукові методи дослідження: історико-порівняльний, історико-синтетичний, історико-діахронний, емпіричного аналізу тощзо.

Ключові слова: туризм, курорт, античний світ, Київька Русь, туристична інфраструктура, туристичні ресурси, рекреачійні комплекс.

Jim. 11.

Anna-Maria URSTA, Master of Tourism, Faculty of Tourism and International Communications Uzhgorod National University (Uzhhorod,Ukraine),ursztika@gmail.com

\section{HISTORY OF DEVELOPMENT OF MAIN DIRECTIONS OF TOURISM IN UKRAINE: SOCIO-ECONOMIC ASPECTS}

The article analyzes the history of development of the main directions of the domestic tourism industry. The author has come to the conclusion that the formation of recreational and tourist activities on the territory of Ukrainian lands took place during the times of ancient Greece. In the Northern Black Sea region colonies were founded, the largest of which were Thira, Olbia, Chersonese, Panticapaeum, Theodosius, Evpatoria, which used medicinal waters, mud of the Crimean lakes and estuaries.

The year 988 was marked by a crucial event in Ukrainian history: Prince Volodymyr of Kiev captured Chersonese (now Sevastopol) and signed an agreement with Byzantium which introduced Christianity throughout Kyivan Rus.

$n$ the thirteenth century, the Venetians and Genoese colonised the Crimean coast, the latter building a majestic fortress at Sudak which to this day towers over the sea rocks. In 1443, Hacl Devlet Giray founded the Crimean Khanate, an independent state with its capital at Bakhchisaray (where the sixteenth-century Khan's palace is currently being considered for inclusion on UNESCO's World Heritage list). During the late eighteenth century, on the waters of the Black Sea, the Ukrainian Cossack commander Sydir Bilyi fought alongside John Paul Jones, the United States' first great naval commander, against the fleet of the Ottoman Empire. It is well known that the conference between the 'Big Three'leaders Churchill, Roosevelt and Stalin-took place in the city of Yalta in 1945. This event defined the shape of the post-war world.

The first mention of the medicinal water deposits in the west of Ukraine (Morshyn, Nemyriv, Polyana, Syniak, Lyuben Velykyi) dates from the XVI century. In the second half of the XVIII century. Rapid development of resorts began in Ukraine. The construction of water treatment centers, hotels, houses for visitors, commercialization of resort business took place, researches and searches of new deposits continued. In Soviet times, the tourism industry was oriented towards recreation. Sanatoriums, large and small health resorts were ole plentifully built.

In the early 90's the tourism industry functioned on the basis of Soviet sanatorium and resort facilities and traveling tourism. 
Disclosure of the theme became possible through the use of general scientific methods of cognition: analysis, synthesis, system, generalization, concreteness, historicism and dialectical method. The scientific research also uses special scientific methods of research: historical-comparative, historical-synthetic, historical-diachronic, empirical analysis, etc.

Key words: tourism, resort, ancient world, Kievan Rus, tourist infrastructure, tourist resources, recreation complex. Ref. 11.

Анна-Мария УРСТА, магистр-туризмознавецьь, факультет туризма и международных коммуникаций ГВУЗ «Ужгородский национальный университет» (Ужгород, Украина), ursztika@gmail.com

\section{ИСТОРИЯ РАЗВИТИЯ ОСНОВНЫХ НАПРАВЛЕНИЙ ТУРИЗМА В УКРАИНЕ: СОЦИАЛЬНО-ЭКОНОМИЧЕСКИЕ АСПЕКТЫ}

В статье проанализирована история развития основных направлений отечественной туристической отрасли. Автор пришла к выводу, что становление рекреационно-туристической деятельности на территории украинских земель происходило ещуе во времена Древней Греции. В Северном Причерноморье были основаньл города-колонии, крупнейтими из которых были Тира, Ольвия, Херсонес, Пантикапей, Феодосия, Евпатория, в которых использовали лечебные воды, грязи крылских озер и лиманов. Первые упоминания о месторождениях лечебных вод на западе Украины (Мориин, Немиров, Поляна, Синяк, Любень Великий) датировань ХVI в. Во второй половине ХVIII в. в Украине началось быстрое развитие курортов. Осуществлялось строительство водолечебнии, гостиниц, домов для приезжих, происходила коммерцииализация курортного дела, продолюсались исследования и поиски новых месторождений. В советское время туристическая отрасль была ориентирована на рекреацию. Массово строились санатории, большие и малье здравницы.

В начале 90-х г2. туристическая отрасль функиионировала основываясь на советских санаторно-курортных объектах и выездном туризме.

Раскрытие темы стало возможным благодаря использованию общенаучных методов познания: анализа, синтеза, системности, обобщения, конкретности, историзма и диалектического. Также использовань специально научные методы исследования: историко-сравнительный, историко-синтетический, историко-диахронный, эмпирического анализа и т.п.

Ключевые слова: туризм, курорт, античный мир, Киевская Русь, туристическая инфраструктура, туристические ресурсы, рекреационные комплекс.

Jim. 11.

Постановка проблеми. Зазначимо, що підгрунтя сучасної рекреаційної діяльності на теренах українських земель були закладені ще в античний період. Саме тоді сформувалося уявлення про ідеальний для відпочинку ландшафт, а прагнення людини отримати якісний відпочинок стало головним соціально-економічним чинником формування потужної індустрії туризму в незалежній Україні, що спонукає до більш детального вивчення означеної проблематики.

Аналіз досліджень. Дослідження історії становлення та розвитку основних напрямів вітчизняного туризму розглянуті у працях В. Абрамова [1], А. Мельника та Ж. Собов [5], В. Федорченка [9], В. Фуртія [10] та ін.

Мета статті - дослідити історію розвитку соціально-економічних аспектів основних напрямів вітчизняного туризму.

Виклад основного матеріалу. Відзначимо, що перші відомі письмові згадки про рекреаційно-туристичну діяльність в Україні сягають часів Давньої Греції. Зокрема, у Північному Причорномор’ї були засновані міста-колонії, найбільшими з яких були:

1. Тіра (Белгород-Дністровський);

2. Ольвія (Миколаївська обл.);

3. Херсонес (сучасна околиця Севастополя);

4. Пантікапей (Керч);

5. Феодосія;

6. Свпаторія.

У зазначених місцевостях використовували лікувальні води, грязі кримських озер і лиманів [6, 46-50]. 
На Русі туристична інфраструктура 3'явилася у XII - XIII ст. Завдяки своєму географічному положенню Київська Русь стала центром, де перехрещувалися торговельні шляхи між Заходом і Сходом, Північчю та Півднем. Налагоджувалися стійкі торговельні відносини, різнобічні культурні та релігійні зв'язки. Після запровадження християнства на Русі з Візантії сюди приїжджали священики, перекладачі, переписувачі книг, ремісники. Маємо констатувати, що на Русі аж до XVI ст. центральною фігурою у встановленні та зміцненні зв'язків з іншими країнами був гість [2].

Зазначимо, що подорожам іноземних гостей надавалось велике значення. Так, київський князь Володимир Мономах у своєму «Поученіі» заповідав синам добре приймати гостей, вшановувати їх, тому що ці люди рознесуть по світу добру або лиху вість.

Попередниками перших закладів розміщення та гостинності на Русі були постоялі двори. Вони називалися «ямами» і розташовувалися на відстані кінного переходу один від одного. У XV ст. постоялі двори створювалися при поштових станціях, що були в підпорядкуванні Ямського наказу. До XV ст. відносять також будівництво у великих містах гостинних дворів, які відрізнялися від постоялих тим, що, крім розміщення і харчування, тут були створені умови для здійснення комерційних операцій. Розселення іноземців у гостинних дворах здійснювалося за національною ознакою [1, 68-172].

Перші згадки про родовища лікувальних вод на заході України - Поляна, Синяк, Моршин, Любень Великий, датовані XVI ст. Так, джерела мінеральних вод Свалявщини, зазначаються у звітах для короля Матяша у 1463 р. У 1709 р. джерела цього району відвідав Ференц II Ракоці. Відзначимо, що мінеральна вода «Свалява» поставлялася до Відня, Парижа, Будапешта, а також на північ у Галицьке королівство. Також відомо про експорт свалявської мінеральної води до Москви (XVII - XVIII ст.) [9, 29-35].

У другій половині XVIII ст. в Україні почався швидкий розвиток курортів. Здійснювалося будівництво:

1. Водолікарень;

2. Готелів;

3. Будинків для приїжджих;

4. Відбувалася комерціалізація курортної справи;

5. Тривали дослідження й пошуки нових родовищ [6, 46-50].

Істотний вплив на розвиток рекреаційно-курортного обслуговування мали праці Ф. Гербера, М. Вороніхіна, Л. Бертенсона, в яких досліджувались й описувалися мінеральні води та грязі Криму і півдня України.

На початку XIX ст. було офіційно відкрито такі курорти, як:

1. Немирів (1814);

2. Трускавець (1827);

3. Одеські грязеві курорти (1830);

4. Саки (1828);

5. Слов'янськ (1828);

6. Приморський (1846) та ін. [3].

На кінець ХІХ ст. припадає створення перших туристичних бюро, що займалися організацією туризму у

1. Ялті;

2. Галичині - Львів, Чернівці, Перемишль.

Відбувається освоєння рекреаційно-туристичних місцевостей, зокрема:

a) Яремчі;

б) Ворохти;

г) Криворівні та ін.

У 1867 р. почало функціонувати Одеське бальнеологічне товариство, де розроблялися методики використання лікувальних факторів, а також правила направлення хворих на курорти. У цей час було розроблено проект закону «Про санітарну і гірську охорону лікувальних місцевостей», до яких відносили місця з джерелами мінеральних вод і лікувальними грязями, морськими купаннями, кумисолікуванням і кліматичні станції, а також прийнято закон про охорону курортів [6, 48-50]. 
Декретом «Про лікувальні місцевості загальнодержавного значення» (1919) проголошувалася націоналізація курортів. У 20-х роках почали функціонувати перші будинки відпочинку - спочатку на Донбасі, а згодом і в інших регіонах України:

1. Миргороді (1917);

2. Слов'янську (1922);

3. курорти Лермонтовський (1925);

4. Ворзель (1932);

5. Березовські мінеральні води (1926) та ін. [1, 192-195].

Найважливішими санаторно-курортними районами України до 1941 р. вважалися:

1. Крим - 168 оздоровниць на 27,5 тис. місць;

2. Одеса - 50 санаторно-рекреаційних закладів, в яких щорічно оздоровлювалися до 150 тис. осіб.

Проблеми грязелікування і бальнеотерапії та інші питання санаторно-курортного лікування досліджуються з 1928 р. Одеським науково-дослідним інститутом курортології [2; 6, 48-50].

Відзначимо, що рекреаційно-туристична діяльність розвивалася й у Західній Україні, яка була поділена між:

1. Польщею - Галичина і Волинь;

2. Румунією - Буковина;

3. Чехословаччиною - Закарпаття.

Найкраще ця галузь була розвинута у Галичині. Тут функціонували курорти європейського значення: Трускавець, Моршин, Черче та Немирів.

Дуже слабко була розвинута санаторно-курортна діяльність на Буковині. Найпопулярнішими туристичними центрами стали: Яремче, Ворохта, Криворівня, Коростів, Гребенів, Славське [3; 8 , 24-27].

Що ж стосується Закарпатської області, майже всі види туризму, які сьогодні культивуються, почали розвивати ще за часів перебування краю у складі Австрійської імперії та Чехословаччини. У складі новоствореної Чехословаччини (1919 - 1939), у краї почали істотно розвиватися літні й зимові, піші й лижні види туризму. Головну роль у масштабному розвитку матеріальної бази галузі зіграв Клуб чехословацьких туристів (ЧСКТ). Його відділення організації надавали методичну і практичну допомогу всім відпочивальникам в організації індивідуальних та групових маршрутів $[11,183-189]$.

Інтенсивний розвиток туризму в Україні припадає на 50-ті рр. Водночас відзначимо, що міжнародний туризм у Радянській Україні був розвинутий слабко. У 60 - 80-х рр. у структурі туристичних послуг акцент робився на екскурсійне обслуговування та організацію планових маршрутів. Так, у 1985 р. участь в екскурсіях брали 43,5 млн. осіб, а тематика екскурсій перевищувала 4,2 тис. найменувань. Туристично-рекреаційні організації України надавали послуг населенню на суму до 368 млн. крб., обслуговуючи 6 млн. туристів [3].

На початку 90-х рр. вітчизняна туристична галузь функціонувала, базуючись на радянських санаторно-курортних об'єктах та виїзному туризмі. Зі здобуттям незалежності України рекреаційно-туристичне господарство контролював Державний комітет молодіжної політики і туризму України. Функціонувало понад 1800 фірм та організацій внутрішнього і міжнародного туризму. 3 прийняттям Закону України «Про туризм» було закладено основи нормативно-правової бази туристичної галузі [6, 48-50; 7, 113-120].

Висновок. Таким чином, огляд проблеми дає підставу зробити висновок, що підгрунтя сучасних напрямів туристичної та рекреаційної діяльності в Україні були закладені ще з XVI ст. Вони базувалися на потужному природному та історико-культурному ресурсному потенціалі українських земель.

Також відзначимо, що у 1950 - 1990 рр. в Україні відбулися істотні зрушення в структурі духовних цінностей суспільства. У XXI ст. явною стає тенденція до використання вільного часу з метою отримання задоволення. 


\section{СПИСОК ВИКОРИСТАНИХ ДЖЕРЕЛ І ЛІТЕРАТУРИ}

1. Абрамов В. В. Історія туризму / В. В. Абрамов, М. В. Тонкошкур. - Харків: Харківська національна академія міського господарства, 2010. - 294 с.

2. Історія розвитку туризму в Україні. Види, форми, класифікація туризму. - [Електронний ресурс]. Режим доступу: http://ua.textreferat.com/referat-941-1.html.

3. Історія розвитку туризму в Україні. - [Електронний ресурс]. - Режим доступу: http://westudents.com. ua/glavy/93659-15-storya-rozvitku-turizmu-v-ukran.html

4. І Історія становлення й розвитку сільського туризму в Карпатському регіоні. - [Електронний ресурс]. Режим доступу: http://5ka.at.ua

5. Мельник А. Особливості становлення організованого туризму Закарпаття (кінець XIX - початок XX століття) / А. Мельник, Ж. Собов // Рекреаційна географія і туризм. Наукові записки. - 2016. - № 2. C. $123-129$.

6. Школа I. Розвиток туристичного бізнесу регіону: моногр. / ред.: I. М. Школа - Чернівці: Кн. - XXI, 2007. $-292 \mathrm{c}$.

7. Товт В. Історія становлення та перспективи розвитку рекреаційно-туристичної зони Закарпатської області / В. Товт // Східноєвропейський історичний вісник / [головний редактор В. Ільницький]. - Дрогобич: Посвіт, 2017. - Вип. 2. - С. 113-120.

8. Тронько П. Т. Краєзнавство у відродженні духовності і культури. Досвід. Проблеми. Перспективи / П. Т. Тронько. - К.: Наук. думка, 1998. -98 с.

9. Федорченко В. К. Історія туризму в Україні: Навчальний посібник / В. К. Федорченко, Т. А. Дьорова. - К.: Вища школа, 2002. - 195 с.

10. Фуртій В. Розвиток туризму на Закарпатті у період Чехословаччини 1918 - 1938 pp. / В. Фуртій // Східноєвропейський історичний вісник / [головний редактор В. Ільницький]. - Дрогобич: Посвіт, 2017. Вип. 3. - С. 114-117.

11. Шандор, Ф. Ф. Становлення туристичної галузі в Закарпатті: історичний аспект [Текст] / Ф. Ф. Шандор // Науковий вісник Ужгородського університету: Серія: Географія. Землеустрій. Природокористування / відп. ред. С. Поп. - Ужгород: Говерла, 2013. - Вип. 1. - С. 183-189.

\section{REFERENCES}

1. Abramov V. V. Istoriia turyzmu / V. V. Abramov, M. V. Tonkoshkur. - Kharkiv: Kharkivska natsionalna akademiia miskoho hospodarstva, 2010. - $294 \mathrm{~s}$.

2. Istoriia rozvytku turyzmu v Ukraini. Vydy, formy, klasyfikatsiia turyzmu. - [Elektronnyi resurs]. - Rezhym dostupu: http://ua.textreferat.com/referat-941-1.html.

3. Istoriia rozvytku turyzmu v Ukraini. - [Elektronnyi resurs]. - Rezhym dostupu: http://westudents.com.ua/ glavy/93659-15-storya-rozvitku-turizmu-v-ukran.html

4. Istoriia stanovlennia y rozvytku silskoho turyzmu v Karpatskomu rehioni. - [Elektronnyi resurs]. - Rezhym dostupu: http://5ka.at.ua

5. Melnyk A. Osoblyvosti stanovlennia orhanizovanoho turyzmu Zakarpattia (kinets XIX - pochatok XX stolittia) / A. Melnyk, Zh. Sobov // Rekreatsiina heohrafiia i turyzm. - Naukovi zapysky. - 2016. - № 2. - S. 123-129.

6. Shkola I. Rozvytok turystychnoho biznesu rehionu: monohr. / red.: I. M. Shkola - Chernivtsi: Kn. - XXI, 2007. $-292 \mathrm{c}$.

7. Tovt V. Istoriia stanovlennia ta perspektyvy rozvytku rekreatsiino-turystychnoi zony Zakarpatskoi oblasti / V. Tovt // Skhidnoievropeiskyi istorychnyi visnyk / [holovnyi redaktor V. Ilnytskyi]. - Drohobych: Posvit, 2017. Vyp. 2. - S. 113-120.

8. Tronko P. T. Kraieznavstvo u vidrodzhenni dukhovnosti i kultury. Dosvid. Problemy. Perspektyvy / P. T. Tronko. - K.: Nauk. dumka, 1998. -98 s.

9. Fedorchenko V. K. Istoriia turyzmu v Ukraini: Navchalnyi posibnyk / V. K. Fedorchenko, T. A. Dorova. - K.: Vyshcha shkola, 2002. - $195 \mathrm{~s}$.

10. Furtii V. Rozvytok turyzmu na Zakarpatti u period Chekhoslovachchyny 1918 - 1938 rr. / V. Furtii // Skhidnoievropeiskyi istorychnyi visnyk / [holovnyi redaktor V. Ilnytskyi]. - Drohobych: Posvit, 2017. - Vyp. 3. - S. 114 117.

11. Shandor, F. F. Stanovlennia turystychnoi haluzi v Zakarpatti: istorychnyi aspekt [Tekst] / F. F. Shandor // Naukovyi visnyk Uzhhorodskoho universytetu: Seriia: Heohrafiia. Zemleustrii. Pryrodokorystuvannia / vidp. red. S. Pop. - Uzhhorod: Hoverla, 2013. - Vyp. 1. - S. 183-189.

Стаття надійшла до редакиіï 15.09.2017 p. 